\title{
4
}

\section{The Treaty of Nice and its critics}

\section{Introduction}

In February 2000, yet another IGC, the fourth since the entry into force of the SEA in 1987, inaugurated its workings with the explicit objective to arrive at a resolution on the so-called 'Amsterdam leftovers'. That is to say, on those decisions that should have been decided upon during the June 1997 Amsterdam Summit, where a pronouncement had not proved possible. This was no easy task given the animosity of the deliberations during the Amsterdam process and the high stakes drawn in case of breakdown and, by extension, a likely collapse of the integration process: the next round of enlargement involving up to twelve new member states from Central and Eastern Europe, Malta and Cyprus. A special Protocol attached to the AMT on 'the enlargement and the institutions of the Union' stated thus:

On the day of the entry into force of the enlargement of the Union and in spite of the provisions of Articles 157.1 TEC, Article 9.1 of the ECSC Treaty and Article 126.1 of the EAEC Treaty, the Commission shall include one citizen per member state provided that, by that date, the weighting of votes in the Council would be modified either through reweighting or through a double majority system, in a manner acceptable to all member states ... Ministers who are members of the General Affairs Council will assume full responsibility for the Conference. ${ }^{1}$

At the second Part of the said Protocol it was stated that:

One year before the number of the member states of the European Union exceeds twenty, an IGC will be convened in order to proceed to a comprehensive reform of ... the composition and functioning of the institutions. ${ }^{2}$

The decision to convene the IGC 2000 was taken at the Cologne European Summit on 4 June 1999. In the resulting Presidency Conclusions, it was stated that: 
The European Council confirms its decision to proceed with an Intergovernmental Conference of the representatives of the member states early in 2000 in order to solve the institutional questions that remained open during the Amsterdam process ... which must be decided upon before enlargement. The IGC must conclude ... at the end of $2000 .^{3}$

As possible items in the IGC agenda, the Cologne Summit proposed the composition and size of the Commission, the reweighting of votes in the Council and the extension of QMV. ${ }^{4}$ The Presidency Conclusions did not fail to point out, however, that other items related to the institutions should have been included, which were not specified at that stage. This was rectified immediately afterwards and, as a result, the IGC agenda expanded. In particular, the December 1999 Helsinki European Council concluded that the

Conference will examine the size and the composition of the European Commission, the weighting of votes in the Council as well as any other necessary changes in the treaties related to the institutions and the implementation of the Treaty of Amsterdam. The next Presidency [Portugal] will report to the European Council on the progress of the Conference and may propose additional items in the agenda of the IGC. ${ }^{5}$

As the report of the Portuguese Presidency to the European Council in Santa Maria de Feira stipulates, ${ }^{6}$ the IGC 2000 should have reached a conclusion on eight issues with the view to preparing the Union for its subsequent round of enlargement. These issues concerned the composition of the major EU institutions (including the Economic and Social Committee (ESC) and the CoR), the weighting of votes in the Council, the extension of QMV, improvements in the procedures on enhanced cooperation ${ }^{7}$ and various minor issues.

Outside the formal confines of the IGC two more issues were taken up: a proposal for a Charter of Fundamental Rights (see Chapter 7) and the common European Security and Defence Policy (see Chapter 6), both of which could have had much more serious and lasting ramifications on the physiognomy of the general system and, more generally, on the future direction of the integration process. It is worth recalling that other important issues were also discussed on the sidelines of the IGC, mainly at the initiative of the Commission, such as the hierarchy of Community Acts and the simplification of the Treaties (see below).

\section{The Commission and the Nice process}

\section{The views of the Commission}

On 1 September 1999, the Commission appointed an ad hoc working group chaired by the former Prime Minister of Belgium, Dehaene, the preceding German President, Weizsäcker, and Lord Simon of Haighbury, chairman of the British Petroleum. The task of the group was to report on institutional reform in view of enlargement. The Dehaene Report was published on 18 October 1999. It 
was structured around a number of initiatives. More specifically, it wished for the broadening of the Cologne agenda to incorporate questions of Treaty simplification and reorganisation, a step of substantial consequence which, had it be taken, it would have led to an altogether different reform outcome (see Chapter 7). It also suggested ways to improve the workings of all the institutions of the Union. Its recommendations on the Commission included the strengthening of the powers of its President and the organisation's overall political direction. Moreover, it was stated that the deficient democratic legitimacy of the larger system entailed that QMV should be generalised and accompanied by parliamentary co-decision in the first pillar and, gradually, in the remaining two. According to the Report, the Amsterdam provisions on enhanced co-operation have not been used owing to an overabundance of built-in inflexible requirements and should therefore be taken up for reform. Transparency and the ensuing enlargement, suggested the Report, point to the reorganisation of the Treaties. This should be done by dividing the existing Treaties into two parts: the first would contain a Basic Treaty, enlisting the general orientations and objectives of the Union, citizens' rights and provisions on the institutional framework. A second, separate part, would include all the other provisions - i.e., common policies - which could be reformed only by a unanimous Council or by a super-qualified majority, after however an opinion of the EP was taken by a reinforced majority. Overall, the Report favoured a substantial simplification of the reform procedures.

The Commission, in its report on institutional adaptation to enlargement, ${ }^{8}$ took on board the Dehaene proposals, pointing out that the issue of the reorganisation of the Treaties had been taken up during the IGC 1996/97, but without success. This issue was also met with the support of the EP. ${ }^{9}$ The simplification of the reform procedures could follow the logic of Art. 95 (2 and 3 ) of the ECSC Treaty that provides for reform of the Treaty provisions without the interference of national parliaments. This so-called 'small reform' facility in the ECSC Treaty, under which the EP must give its approval by a $2 / 3$ or $12 / 15$ majority, was also suggested by the first Report of the European University Institute (EUI), in a study undertaken at the Commission's request. ${ }^{10}$ Briefly, the EUI Report suggested the following (see also Chapter 7): first, that Treaty simplification makes sense only in the cases of the TEC and the TEU. Second, that the TEU, as reformed by the AMT, should be replaced by a Basic Treaty, which would include only the fundamental provisions of the TEC and the TEU. The rest of the provisions would be attached to the Basic Treaty in the form of Protocols. In this way, Treaty simplification becomes a straightforward exercise. A second EUI Report considered whether a possible simplification of the Treaties might also require a change in the reform procedures themselves. Here, the EUI suggested that unanimity should be abolished during the reform process and be replaced by a super-qualified majority with a right of opt-out to those member states that would find themselves in a minority position. The Report also recommended the strengthening of 'autonomous' reform procedures - i.e., the 
ECSC small-reform model; the need for organising better the work of European Councils at the end of review conferences to improve the quality of its decisiontaking; and that the Convention model, as applied in the case of the Charter of Fundamental Rights, be used as a vehicle for formal treaty change.

\section{Discussions in the IGC on the Commission}

During the IGC 2000, those negotiations that were of consequence to the Commission focused on the need to find suitable ways to preserve the fundamental principle of its working method - i.e., collective responsibility - in view of prospective enlargements and the resulting increase in its membership. In its opinion on the IGC, the Commission emphasised this very point by stating that

The Commission reaches thousands of decisions each year ... approximately 200 per week ... is embarking upon a reorganisation of its internal services . . because after the enlargement the preservation of its collective responsibility will be a far more difficult exercise. ${ }^{11}$

The Commission suggests that in a Union of twenty-five-twenty-seven members, a Commission of thirty-three-thirty-five members would find it all the more difficult properly to exercise its leadership and, hence, the IGC should reach an agreement on its future composition. The Commission itself has put forward two alternative scenarios: the first referred to a system of rotating membership, whereby the order of membership had to be explicitly mentioned in the Treaties and under which every member state would have one Commissioner in every five out of seven Commissions. ${ }^{12}$ The second scenario involved a system whereby each member state would have the right to nominate one Commissioner. This would lead to a Commission of thirty-five members in a Union of twenty-eight (including Turkey) - or, a Commission of thirty-three members were Turkey to be excluded - under the existing system in which the bigger member states have two Commissioners each. This scenario was advanced with the proviso that there would be a massive reorganisation of the Commission to enable it to offset any possible functional difficulties resulting from an increase in its size. ${ }^{13}$

The Commission Report also emphasised the need to increase the powers of its President and the way of his/her election. In particular, it was suggested that the President should be able to dismiss individual Commissioners for serious misconduct or inefficiency during their term of office. This would strengthen the position of the President and would allow him/her to apply his/her political leadership function more efficiently than presently. A different way of electing the Commission President was also in order according to the Report with the view to bestowing the political system of the EU with a higher degree of democratic legitimacy. Table 4.1 shows the Treaty provisions related to the Commission that were discussed in the IGC 2000.

In the IGC discussions, significant changes in Arts 219 (para. 2), 217 and 215 were tabled even if the results obtained were more modest than originally hoped for by the Commission. To give an example, a change common to the Law 
Table 4.1 Treaty provisions related to the Commission

\begin{tabular}{ll}
\hline Article & Subject \\
\hline 219 TEC first paragraph & $\begin{array}{l}\text { The Commission functions under the } \\
\text { political guidance of its President } \\
219 \text { TEC second paragraph }\end{array}$ \\
217 TEC & $\begin{array}{l}\text { The Commission decides with the majority of } \\
\text { its members }\end{array}$ \\
& $\begin{array}{l}\text { The Commission elects two Vice-Presidents } \\
\text { from among its members }\end{array}$ \\
& $\begin{array}{l}\text { The Commission decides on its Rules of } \\
\text { Procedure }\end{array}$ \\
\hline
\end{tabular}

Table 4.2 Proposed changes in Art. 217

\begin{tabular}{|c|c|c|}
\hline Art. 217 & Proposed new Article & IGC Conclusion \\
\hline \multirow[t]{3}{*}{$\begin{array}{l}\text { The Commission may elect } \\
\text { two Vice-Presidents from } \\
\text { among its members. }\end{array}$} & $\begin{array}{l}\text { The President will determine } \\
\text { the political orientation of } \\
\text { the Commission. }\end{array}$ & $\begin{array}{l}\text { The Commission works } \\
\text { under the political } \\
\text { guidance of its President } \\
\text { who determines its } \\
\text { internal organisation, } \\
\text { and that it functions } \\
\text { efficiently on the basis of } \\
\text { collective responsibility. }\end{array}$ \\
\hline & $\begin{array}{l}\text { The President may appoint } \\
\text { two vice Presidents from } \\
\text { among its members. }\end{array}$ & $\begin{array}{l}\text { The functions of the } \\
\text { Commission will be } \\
\text { structured and allocated } \\
\text { to its members by the } \\
\text { President. The President } \\
\text { during the } \\
\text { Commission's term of } \\
\text { office may reshuffle } \\
\text { portfolios. On the } \\
\text { agreement of the } \\
\text { Commission, the } \\
\text { President may appoint } \\
\text { Vice-Presidents from } \\
\text { among its members. }\end{array}$ \\
\hline & $\begin{array}{l}\text { The President may entrust } \\
\text { members of the Commission } \\
\text { with special duties and } \\
\text { responsibilities for part or the } \\
\text { whole of their term of office. }\end{array}$ & $\begin{array}{l}\text { On the agreement of the } \\
\text { Commission, the } \\
\text { President may demand } \\
\text { the resignation of } \\
\text { individual members. }\end{array}$ \\
\hline
\end{tabular}


Table 4.3 Member state positions on the Commission

\begin{tabular}{|c|c|}
\hline Member state & Position \\
\hline Belgium & $\begin{array}{l}\text { One Commissioner per member state, appointment of the } \\
\text { Commission by common accord of national governments, } \\
\text { strengthening of the President, no hierarchy of } \\
\text { Commissioners }\end{array}$ \\
\hline Denmark & $\begin{array}{l}\text { One Commissioner per member state, more Vice-Presidents, } \\
\text { internal reorganisation of the Commission }\end{array}$ \\
\hline Germany & Limit to the size of the Commission \\
\hline Greece & $\begin{array}{l}\text { One Commissioner per member state, more Vice-Presidents, } \\
\text { internal reorganization of the Commission }\end{array}$ \\
\hline France & Limit to the size of the Commission \\
\hline Ireland & $\begin{array}{l}\text { One Commissioner per member state, more Vice-Presidents, } \\
\text { internal reorganisation of the Commission }\end{array}$ \\
\hline Italy & Limit to the number of Commissioners \\
\hline Luxembourg & $\begin{array}{l}\text { One Commissioner per member state, appointment of the } \\
\text { Commission by common accord of national governments, } \\
\text { strengthening of the President, no hierarchy of } \\
\text { Commissioners }\end{array}$ \\
\hline Netherlands & $\begin{array}{l}\text { One Commissioner per member state, appointment of the } \\
\text { Commission by common accord of national governments, } \\
\text { strengthening of the President, no hierarchy of } \\
\text { Commissioners }\end{array}$ \\
\hline UK & Limit to the number of Commissioners \\
\hline Spain & Limit to the number of Commissioners \\
\hline Portugal & $\begin{array}{l}\text { One Commissioner per member state, more Vice-Presidents, } \\
\text { internal reorganisation of the Commission }\end{array}$ \\
\hline Austria & $\begin{array}{l}\text { One Commissioner per member state, more Vice-Presidents, } \\
\text { internal reorganisation of the Commission }\end{array}$ \\
\hline Sweden & $\begin{array}{l}\text { One Commissioner per member state, more Vice-Presidents, } \\
\text { internal reorganisation of the Commission }\end{array}$ \\
\hline Finland & $\begin{array}{l}\text { One Commissioner per member state, more Vice-Presidents, } \\
\text { internal reorganisation of the Commission }\end{array}$ \\
\hline
\end{tabular}

of Associations was suggested, that the Commission may reach a decision by a majority of its members but in case of a split vote, the side including the vote of its President wins through. ${ }^{14}$ This addition, however, was not accepted by the IGC. More significant still were the changes proposed for Art. 217, ${ }^{15}$ according to which the President of the Commission would have acquired more powers vis-à-vis the rest of the Commissioners and would have been elevated from his 
current primus inter pares status. Table 4.2 shows the proposed changes to Art. 217 by the Commission and the IGC conclusions.

Table 4.3 supplies information on the positions adopted by the member state representatives during the IGC on the Commission. On the basis of the data presented by Table 4.3, it seems that the bigger countries demanded a limit to the number of Commissioners. In most cases in the positions of the bigger countries there is no mention on the internal reorganisation of the Commission as a serious enough issue to warrant attention in the official documents produced during the IGC. On the contrary, the smaller members made an issue of the size and the political role of the Commission, being unanimously behind the initiative on its internal reorganisation, insisting on the principle of one Commissioner per member state, while rejecting any limit to the size of the Commission. The smaller members also rejected the hierarchy among Commissioners, but on the whole supported an increase in the number of VicePresidents.

\section{Changes with the Treaty of Nice}

The result of the IGC deliberations and the negotiations that took place during the December 2000 Nice Summit are shown in Table 4.4 .

Table 4.4 Summary of the provisions on the Commission in the Treaty of Nice

\begin{tabular}{lll}
\hline Subject & Arrangement & Time \\
\hline Size of the Commission & $\begin{array}{l}\text { One Commissioner per } \\
\text { member state }\end{array}$ & 1 January 2005 \\
Powers of the President & $\begin{array}{l}\text { Increase in the powers of } \\
\text { the President } \\
\text { Responsibility for the internal } \\
\text { organisation of the Commission } \\
\end{array}$ & $\begin{array}{l}\text { On the Commission's accord, } \\
\text { Treaty of Nice } \\
\text { the President can ask a member } \\
\text { to resign }\end{array}$ \\
Rotating membership & $\begin{array}{l}\text { When the 27th member joins } \\
\text { the Union }\end{array}$ & Unknown \\
Internal reorganisation & & In progress \\
\hline
\end{tabular}

In the Protocol on the 'enlargement of the Union', ${ }^{16}$ and particularly in its Art. 4, it is stated that Art. 213 TEC would be amended to reflect the changes decided at the IGC 2000 and the Nice Summit. More specifically, it was decided that Art. 213(1) would be so revised so that the Commission would consist of 
one Commissioner per member state, effective on 1 January 2005. Such a decision was accompanied with an unspecified system of rotation - with the explicit task of ensuring both geographical as well as demographic balance in the college of Commissioners - which will be effective for the first Commission appointed after the twenty-seventh member joins the Union. The Council, acting unanimously, will decide on the number of Commissioners and the system of rotation, with due attention to the preservation of a working equilibrium between the member states. More important, though, proved the changes inflicted upon the process of electing the new Commission and its President. The whole system now evolves in four phases and has been aptly communitarised. The new Art. 214 TEC specifies that the new President will be elected by QMV by the European Council acting as General Affairs Council. This is Phase I of the new and quite lengthy process. Phase II involves the EP, which must approve the Council's choice. Were that to be the case, then (Phase III) the chosen President and the General Affairs Council, acting by QMV, will draw up a list of the members of the new Commission on the basis of proposals received by the member states. The President and his/her Commissioners must be approved en bloc by the EP. Finally (Phase IV), following the approval of the EP, the new Commission and its President must be appointed by the General Affairs Council (with the European Council again acting as General Affairs Council) on the basis of QMV.

Changes were also introduced in Art. 215 TEC regarding the powers of the Commission President. Under the revised arrangement of Art. 215 (para. 2), any member of the Commission who resigned, was forced to resign, or died will be replaced by the Council acting by QMV. It should be noted though that under the revised Art. 215 (para. 4) it becomes feasible for a unanimous Council to decide not to replace a member of the Commission who does not fulfill his/her duties on the above-stated grounds. Under the revised Art. 217, the position of the Commission President is strengthened, although not at the extent originally desired by the Commission. The President is now responsible for the internal organisation of the Commission in order to protect its principle of collective responsibility, as well as its internal effectiveness and cohesion. Para. 2 in Art. 217 offers the President the opportunity to reshuffle the responsibilities of individual Commissioners during their term of office. This is an important development and is expected to lessen the intergovernmental grip upon the Commission, and in particular the horse-trading associated with the allocation of Commission portfolios among the member state governments. Moreover, the President, after obtaining the Commission's agreement, can appoint Vice-Presidents whose number is not specified, thus increasing his/her margin of manoeuvre in the allocation of competences in the body. Finally, para. 4 of the same Article stipulates that the President, after obtaining the agreement of the Commission, may request the resignation of a member of the Commission. Overall, therefore, the hold of the President is strengthened as a result of the NIT. 


\section{Decision-making in the Council}

Reweighting of votes or a different voting system in the Council (double majority system) was the demand put forward by the AMT, as mentioned earlier in this chapter. This was probably the more important element in the institutional package that became subject to an extensive and arduous negotiation during the IGC 2000 and the Nice Summit. In general terms, the deliberations in the IGC evolved along two alternative scenarios: reweighting of votes in favour of the bigger member states, which might have lost their second Commissioner, or a system of double majority voting. In each system, there are pros and cons, as will be discussed below. The Report of the Portuguese Presidency at the Santa Maria de Feira European Council mentioned that there was convergence in the IGC on the following five points: ${ }^{17}$

- Any chosen system should reflect the double nature of the Union, in the form of a union of states and a union of peoples.

- The chosen system should guarantee equity between the member states, transparency and effectiveness in the workings of the Council, and should also be simple and easily comprehensible by the citizens of the member states.

- Any chosen system should represent at least 50 per cent of the population of the Union.

- The reweighting of the votes is part and parcel of the issues of the composition of the Commission and the allocation of seats in the EP.

- Any chosen system should facilitate decision-making in the Council.

Table 4.5 illustrates the existing weighting of Council votes and the population of the member states as reported by Eurostat in 1999.

Table 4.5 Weighting of votes and population of the member states

\begin{tabular}{lcc}
\hline Member state & Population $(\mathrm{m})$ & Number of votes \\
\hline Germany & 82,038 & 10 \\
UK & 59,247 & 10 \\
France & 58,966 & 10 \\
Italy & 57,612 & 10 \\
Spain & 39,394 & 8 \\
Netherlands & 15,760 & 5 \\
Greece & 10,533 & 5 \\
Belgium & 10,213 & 5 \\
Portugal & 9,980 & 5 \\
Sweden & 8,854 & 4 \\
Austria & 8,082 & 4 \\
Denmark & 5,313 & 3 \\
Finland & 5,160 & 3 \\
Ireland & 3,744 & 3 \\
Luxembourg & 429 & 2 \\
Total & 375,325 & 87 \\
\hline
\end{tabular}


On the basis of the data provided by Table 4.5, a decision by the Council requires 62 out of 87 votes. These 62 votes in percentage terms represent 71.26 per cent of the total votes in the Council and require the votes of at least eight member states. This is the minimum number of states required for a decision to be reached. This minimum number also represents 58.16 per cent of the combined population of the fifteen members. Conversely, 26 votes cast are required for the rejection of a proposal by at least three member states representing 12.38 per cent of the Union's population. In theory, only three of the bigger member states with 10 votes each may form a blocking minority. Table 4.6 shows the informal population threshold as it has evolved in the EU since 1958.

Table 4.6 shows that in every instance since 1958 any decision taken by QMV was always the expression of the majority of the member states and, more importantly, of the majority of the population. Tables $4.7-4.9$ project the current QMV system to an EU of twenty-seven or twenty-eight members.

Table 4.6 Informal population threshold since 1958

\begin{tabular}{lcccc}
\hline EEC 6 (\%) & EEC 9 (\%) & EEC 10 (\%) & EEC 12 (\%) & EU 15 (\%) \\
67.71 & 70.49 & 70.14 & 63.27 & $59.83^{\mathrm{a}}$ \\
& & & 58.18 & \\
\hline
\end{tabular}

Note: ${ }^{a}$ This was after German reunification.

On the basis of the data provided in Table 4.7, under the existing decisionmaking system - i.e., before the entry into force of the NIT - for a decision to be blocked it requires 43 votes cast by at least five member states representing 10.45 per cent of the combined population of the member states. Moreover, according to the same data, a blocking minority can be formed by eight new enlargement member states, for example by Turkey, Poland, Rumania, the Czech Republic, Bulgaria, Lithuania, Hungary and Malta (total votes 44). Turkey alone could cover the minimum required population threshold! In an Union of twenty-seven members, the danger of blocking minorities formed exclusively by the new member states is more remote because of the absence of Turkey. In the system under discussion there is no compensation for those member states that lose their second Commissioner. The double majority systems discussed in the IGC exhibit a number of interesting features and advantages. Table 4.10 offers the necessary information.

Population weights add up to 1,000 and thus become easy to verify whether a decision taken carries the necessary population support, as expressed by the percentage of the combined population of the member states supporting a particular decision. For the approval of a proposal, a majority of the member states is required - i.e., fourteen member states in an EU-27 and the satisfaction of the existing population threshold of 58.2 per cent. For the rejection of a proposal, 
Table 4.7 Existing QMV system projected for EU-27 and EU-28

\begin{tabular}{|c|c|c|}
\hline Member state & Number of votes & Population \\
\hline Germany & 10 & 82,038 \\
\hline Turkey & 10 & 64,385 \\
\hline UK & 10 & 59,247 \\
\hline France & 10 & 58,966 \\
\hline Italy & 10 & 57,612 \\
\hline Spain & 8 & 39,394 \\
\hline Poland & 8 & 38,667 \\
\hline Romania & 6 & 22,489 \\
\hline Netherlands & 5 & 15,760 \\
\hline Greece & 5 & 10,533 \\
\hline Czech Rep. & 5 & 10,290 \\
\hline Belgium & 5 & 10,213 \\
\hline Hungary & 5 & 10,092 \\
\hline Portugal & 5 & 9,980 \\
\hline Sweden & 4 & 8,854 \\
\hline Bulgaria & 4 & 8,230 \\
\hline Austria & 4 & 8,082 \\
\hline Slovakia & 3 & 5,393 \\
\hline Denmark & 3 & 5,313 \\
\hline Finland & 3 & 5,160 \\
\hline Ireland & 3 & 3,744 \\
\hline Lithuania & 3 & 3,701 \\
\hline Latvia & 3 & 2,439 \\
\hline Slovenia & 3 & 1,978 \\
\hline Estonia & 3 & 1,446 \\
\hline Cyprus & 2 & 752 \\
\hline Luxembourg & 2 & 429 \\
\hline Malta & 2 & 379 \\
\hline Total EU-28 & 144 & 545,566 \\
\hline Total EU-27 & 134 & 481,181 \\
\hline
\end{tabular}

Table 4.8 EU-28

\begin{tabular}{lcccc}
\hline & Votes & \% of votes & $\begin{array}{c}\text { Minimum } \\
\text { number and (\%) } \\
\text { of member states }\end{array}$ & $\begin{array}{c}\text { Minimum \% of } \\
\text { population }\end{array}$ \\
\hline QMV & 102 & 70.83 & $14(50.0)$ & 51.36 \\
Blocking minority & 43 & 29.86 & $5(17.9)$ & 10.45 \\
Total & 145 & & & \\
\hline
\end{tabular}


Table 4.9 EU-27

\begin{tabular}{lcccc}
\hline & Votes & \% of votes & $\begin{array}{c}\text { Minimum } \\
\text { number and (\%) } \\
\text { of member states }\end{array}$ & $\begin{array}{c}\text { Minimum \% of } \\
\text { population }\end{array}$ \\
\hline QMV & 96 & 71.64 & $14(51.85)$ & 50.20 \\
Blocking minority & 39 & 29.10 & $4(14.81)$ & 10.50 \\
Total & 135 & & & \\
\hline
\end{tabular}

Table 4.10 Double majority systems

\begin{tabular}{|c|c|c|}
\hline Member state & Population weight EU-28 & Population weight EU-27 \\
\hline Germany & 150 & 169 \\
\hline Turkey & 118 & - \\
\hline UK & 109 & 123 \\
\hline France & 108 & 123 \\
\hline Italy & 106 & 120 \\
\hline Spain & 72 & 82 \\
\hline Poland & 71 & 80 \\
\hline Romania & 41 & 47 \\
\hline Netherlands & 29 & 33 \\
\hline Greece & 19 & 22 \\
\hline Czech Rep. & 19 & 21 \\
\hline Belgium & 19 & 21 \\
\hline Hungary & 18 & 21 \\
\hline Portugal & 18 & 21 \\
\hline Sweden & 16 & 18 \\
\hline Bulgaria & 15 & 17 \\
\hline Austria & 15 & 17 \\
\hline Slovakia & 10 & 11 \\
\hline Denmark & 10 & 11 \\
\hline Finland & 9 & 11 \\
\hline Ireland & 7 & 8 \\
\hline Lithuania & 7 & 8 \\
\hline Latvia & 4 & 5 \\
\hline Slovenia & 4 & 4 \\
\hline Estonia & 3 & 3 \\
\hline Cyprus & 1 & 2 \\
\hline Luxembourg & 1 & 1 \\
\hline Malta & 1 & 1 \\
\hline Total EU-27 & 1,000 & 1,000 \\
\hline
\end{tabular}


again a majority of the member states is required or, alternatively, four member states whose population adds up to 419 units $(1,000-582=418+1=419)$ representing 11.62 per cent of the combined population in the Union. A simple majority is required for the adoption or the rejection of a particular proposal. There is no weighting of votes and each member state has only one vote. The paradox in this approach relates to the fact that the higher the population threshold for the approval of a proposal the smaller it becomes for its rejection. The difficulty here is self-evident: there is no compensation to the bigger member states for the loss of their second Commissioner. In addition, such a system does not take into account the differences in the political weight of the member states, thus making it less popular with some of them. Had the political problem of the physiognomy of the Union been resolved, this system would have been a front-runner. A version of a double majority system which combines features from the existing QMV arrangements was also discussed in the IGC as shown in Table 4.11

Table 4.11 Double majority system with features of existing QMV arrangements

\begin{tabular}{lcccccc}
\hline & Votes & $\begin{array}{c}\text { Population } \\
\text { weight }\end{array}$ & \% of votes & $\begin{array}{c}\text { Minimum } \\
\text { number and } \\
(\%) \text { of } \\
\text { member states }\end{array}$ & $\begin{array}{c}\text { Minimum \% } \\
\text { of population }\end{array}$ \\
\hline QMV & 102 & and & 582 & 70.83 & $14(50.00)$ & 58.20 \\
$\begin{array}{l}\text { Blocking } \\
\text { minority }\end{array}$ & 33 & or & 419 & 29.86 & $4(14.29)$ & 10.45 \\
Total & 135 & & & & & \\
\hline
\end{tabular}

The difference between this and the previous system has to do with the fact that this system requires a weighted instead of a simple majority for the rejection or approval of a decision. Thus, this system takes due account of the differences in political (and economic) weight between the member states. The population threshold is the same as in the previous system - i.e., 58.2 per cent, that under the QMV system currently in force. Adoption of a proposal requires 102 out of 135 votes cast by at least fourteen member states which gather between them 582 units ( 58.2 per cent population threshold required). The blocking minority consists of 33 weighted votes $(135-102=32+1=33)$ or, alternatively, by 419 units from four member states. The QMV threshold is at normal levels inside the 1958-2000 average (70 per cent). The 'deficiency' of this version of a double majority system is that there is no compensation for the loss of the second Commissioner on the part of the bigger members, although a version taking account of just that could have been easily recommended. 


\section{Changes in the weighting system with the Treaty of Nice}

The issue was finally resolved in the December 2001 Nice Summit. After a marathon session, the Summit concluded in favour of a system resembling the last system discussed above with some interesting features borrowed from the double majority models; Table 4.12 supplies the details. In Art. 3 of the Protocol on the enlargement of the Union, which was attached to the NIT, it is stated that the above changes will come into force on 1 January $2005 .{ }^{18}$ In effect, this is the necessary transitional stage required for the smooth accession of the new members. When the Council decides on a proposal from the Commission, the QMV is set at 169 out of 237 votes cast by at least the majority of the member states (eight), expressing at least 62 per cent of the population of the Union, which is a specific Treaty requirement (see below). The blocking minority is set at 69 out of 237 votes, which can be formed by at least three member states representing 30.6 per cent of the combined population of the Union (Italy, Spain and the Netherlands are used in the above example - i.e., $29+27+13=69$ ). The point is that this blocking minority can be easily formed by a number of combinations between the member states. Three bigger member states can reach the required level of votes $(29 \times 3=87)$, which is something that may happen at the existing QMV system as shown in Table 4.12. On the whole the votes of the bigger member states nearly tripled, from 10 to 29 , those of the medium-size member states more than doubled (for example, Belgium, Portugal and Greece moved from 5 to 12 votes with the Netherlands winning an additional vote, moving from 5 to 13). The countries of the northern EU enlargement moved from 4 to 10 votes with the exception of Finland (and Ireland), which moved from 3 to 7

Table 4.12 EU-15: new weighting of votes in view of enlargement

\begin{tabular}{lccr}
\hline Member state & QMV in force & New QMV & Population \\
\hline Belgium & 5 & 12 & 10,213 \\
Denmark & 3 & 7 & 5,313 \\
Germany & 10 & 29 & 82,038 \\
Greece & 5 & 10 & 10,533 \\
France & 10 & 29 & 58,966 \\
Ireland & 3 & 7 & 3,744 \\
Italy & 10 & 29 & 57,612 \\
Luxembourg & 2 & 4 & 429 \\
Netherlands & 5 & 13 & 15,760 \\
UK & 10 & 29 & 59,247 \\
Spain & 8 & 27 & 39,394 \\
Portugal & 5 & 12 & 9,980 \\
Austria & 4 & 10 & 8,082 \\
Sweden & 4 & 10 & 8.854 \\
Finland & 3 & 7 & 5,160 \\
QMV & $62 / 87(26)$ & $169 / 237(69)$ & \\
\hline
\end{tabular}


votes and seem to be on the losing side in that regard. The bigger gains seem to be those of Spain, which moved from 8 votes at the current system to 27 at the new one. In fact, Spain demanded during the IGC to have the same number of votes as Germany, France, Italy and the UK, while France contributed to the near-collapse of the Nice Summit by refusing to have fewer votes than Germany. Table 4.13 shows the allocation of votes in the Council as agreed at Nice for the enlarged Union.

Table 4.13 EU-27: weighting of votes

\begin{tabular}{|c|c|c|}
\hline Member state & Population & New weighting of votes \\
\hline Germany & 82,038 & 29 \\
\hline UK & 59,247 & 29 \\
\hline France & 58,966 & 29 \\
\hline Italy & 57,612 & 29 \\
\hline Spain & 39,394 & 27 \\
\hline Poland & 38,667 & 27 \\
\hline Romania & 22,489 & 14 \\
\hline Netherlands & 15,760 & 13 \\
\hline Greece & 10,533 & 12 \\
\hline Czech Rep. & 10,290 & 12 \\
\hline Belgium & 10,213 & 12 \\
\hline Hungary & 10,092 & 12 \\
\hline Portugal & 9,980 & 12 \\
\hline Sweden & 8,854 & 10 \\
\hline Bulgaria & 8,230 & 10 \\
\hline Austria & 8,082 & 10 \\
\hline Slovakia & 5,393 & 7 \\
\hline Denmark & 5,313 & 7 \\
\hline Finland & 5,160 & 7 \\
\hline Ireland & 3,744 & 7 \\
\hline Lithuania & 3,701 & 7 \\
\hline Latvia & 2,439 & 4 \\
\hline Slovenia & 1,978 & 4 \\
\hline Cyprus & 752 & 4 \\
\hline Luxembourg & 429 & 4 \\
\hline Malta & 379 & 3 \\
\hline Total EU-27 & 481,181 & \\
\hline QMV EU-27 & $258 / 345$ & \\
\hline
\end{tabular}

In both cases shown above, it seems that the Nice European Council did not accept the introduction of a double majority system, but only elements of it in the form of a required population threshold for the taking of a decision in the Council (62 per cent) instead of the far simpler and more legitimate versions discussed during the IGC. This population criterion though is not a 
condition for the taking of a Council decision. It becomes one only if one or more member states demand verification, in that any taken decision in fact reflects the 62 per cent population requirement. Even so, this system does not include a weighting of the population like the double majority systems discussed during the IGC and as such the verification process may run into difficulties. As the Protocol on the Enlargement and the Final Declaration of the review conference states:

When the Council acts on a qualified majority, one of its members may demand verification that the qualified majority consists of 62 per cent of the total population of the Union. If this condition is not met the decision will not be taken. ${ }^{19}$

Overall, the new system resembles the one discussed during the IGC, a system on the lines of the existing one, but with adjustments in favour of the bigger states, compensating them for their eventual loss of their second Commissioner. It should be reminded that the new QMV system will come into force on 1 January 2005 at the same date as the provisions on the Commission (see above). The system itself, which in fact represents a neorealist triumph, bears some marks of a compromise struck in the Nice Summit with reference to the population threshold, thus adding a double majority perspective in the agreed system. The QMV threshold set at nearly 75 per cent, mainly at the insistence of Germany, brings the whole system one step backwards towards the direction of unanimity, and is expected to complicate the taking of decisions in the first pillar. Overall, it seems that the bigger member states (the 'big four' plus Spain) increase their influence under the new system disproportionately in comparison with the rest of the member states. It also seems that the bigger states during the Nice negotiations acted in concert to achieve a reweighting of votes in their favour. The informal institutional implications of such a practice, if sustained, are pretty obvious: the bigger member states occupy the driving seat in the general system.

If we attempt to judge the new system using the criteria mentioned in the Feira Report, it is possible to conclude that not a single condition was fulfilled: the chosen system only partially reflects the double nature of the Union as a union of states and a union of peoples, and it adds little to the need for more transparency and effectiveness in the workings of the Council; in fact, it can be safely argued that it does exactly the opposite. Moreover, it is not a system that can claim the simplicity required to be easily comprehensible by the citizens of the member states and does not seem to be facilitating decision-making in the Council. Wessels makes the same point, stating that there are still 38(!) different ways for the Council and the EP to interact in decision-making and 11(!) different ways of decisionmaking in the Council. ${ }^{20}$ In summary, the new system in a Union of twenty-seven or more states consists of three interrelated qualifications: the majority of the member states, a qualified majority, and a population threshold. 


\section{The other institutions and the Nice process}

\section{The EP}

The EP formally presented its views on the basis of Art. 48 (2) TEU. ${ }^{21}$ They were structured around three main lines of argument: first, the EP called for a more democratic process of union on rather conventional lines, with its membership not exceeding the Amsterdam threshold and a transitional period for accommodating the MEPs from the new member states. Second, it suggested that there should be a provision inserted in the Treaty related to the 2009 Euro-elections, according to which 10 per cent of the EP's membership will be elected in a single constituency with two lists, one European and one national. This means that the EP is proposing a limited transfer of the German electoral system at the larger level. The pro-federal features of this suggestion are evident and need no further comment! Third, regarding both the operation and organisation of EU-level political parties, the EP proposed the following change in the wording of Art. 191:

The European political parties contribute to the development of a European consciousness and the expression of the political will of the peoples of Europe. On a proposal from the Commission, the EP and the Council, on the Article 251 procedure, will lay down the criteria, the rules and the procedures for financing (including Community financing) the European political parties. ${ }^{22}$

It is clear that the debate on European political parties is closely linked to their financial links with the national level, an issue with serious political ramifications in some member states such as Germany, Greece and Italy, among others. In any case, there should be greater transparency on this issue given that the EU experiment cannot afford further legitimation crises. The financing of political parties at the European and national levels must be two altogether separate issues. Moreover, it is a well-documented fact that the EP lacks a permanent seat. Its plenary sessions are held in Strasbourg and Luxembourg and its committees meet in Brussels. Apart from the South African Parliament during the period of Apartheid it is the only other Parliament whose seat is different from the seat of the Executive. To address this long-standing problem, the EP has suggested the following new provision in the NIT: 'The EP with an absolute majority of its members will decide on the location of its permanent seat where all its meetings would be taking place. ${ }^{23}$

As far as the structure and workings of the Council are concerned, the EP proposed its reorganisation along federal lines, again without any serious prior debate on the justification of these proposals. As such, the Council should decide on the basis of a double majority system, should become accountable for its acts or its omissions to act on the EP and should be divided into an executive and a legislative Council. ${ }^{24}$ The Commission President should be elected by the EP from a list drawn up by the Council and should have sufficient power to dismiss individual members of the Commission for serious misconduct during 
their period of office. The same right, the EP suggests, should be given to the EP on the basis of Art. 216, that is after the EP's application to the ECJ. ${ }^{25}$

On the issue of the reorganisation of the ECJ, the EP suggested that it should consist of a number equal or higher to the number of the member states. The Court of First Instance should be given the right to deliver opinions on the basis of the Art. 234 procedure (preliminary ruling). The jurisdiction of the ECJ should be extended to all the issues in Title VI of the TEC (visa, asylum, free movement of persons including migration) and Title VI of the TEU (Judicial and Police Cooperation). The EP should be given the same right afforded to the Council and the Commission to appeal in front of the ECJ by reforming the provisions of Arts 230 and 232 TEU.

Unanimity in the Council should be limited to all issues of constitutional nature with parliamentary co-decision being the main decision-making mechanism in the Union. The Treaties should be simplified on the basis of the EUI Reports (see above), the Charter of Fundamental Rights should be incorporated into the Treaties (see Chapter 7), and a hierarchy of Community Acts be duly established. The enhanced co-operation provisions in the AMT should be reformed to enable a smaller number of states to take the initiative for flexible integration schemes and the various restrictions attached in the AMT should be eased. Finally, the EP called for the setting up of a new institution, the European Prosecutor's Office, to combat fraud in the EU. ${ }^{26}$ Table 4.14 summarises the position of the EP during the IGC 2000.

Table 4.14 Views of the European Parliament (EP)

\begin{tabular}{ll}
\hline Hierarchy of Community Acts & Yes \\
Incorporation of the Charter of Fundamental Rights in the Treaties & Yes \\
Unanimity in the Council abolished & Yes \\
Loosened enhanced co-operation provisions & Yes \\
Double majority system in the Council & Yes \\
Co-decision and QMV main decision-making mechanisms & Yes \\
Reform of the ECJ and of the Court of First Instance & Yes \\
One Commissioner per member state & Yes until 2010 \\
Simplification of the Treaties & Yes \\
Gradual abolition of the pillar system & Yes \\
Generalisation of the ascent procedure & Yes
\end{tabular}

Table 4.15 shows the results of the negotiations during the Nice Summit on the allocation of seats in the EP in an EU-27. It reflects the third element in the package deal agreed in the Nice Summit besides the size and composition of the 
Commission and the weighting of votes in the Council. The French refusal during the negotiation for the reweighting of Council votes to accept more votes for Germany preordained that from the 'big four' countries only Germany managed to come out of the negotiations without any losses in the new allocation of seats in the EP. Indeed, all current EU members lose seats, save for Germany and Luxembourg, who retain the same number of seats. France, Italy and the UK lose 15 seats each and Spain loses 14. The four bigger states and Spain lose 59 seats between them, whereas the other members lose from 3 to 6 seats each. It seems that in the new EP, and especially that of 2009-14, one-seventh of all Members of the European Parliament (MEPs) will be coming from Germany. Hungary and the Czech Republic are the losers in the new system, having fewer seats than countries with similar population sizes. The total number of seats is

Table 4.15 Allocation of seats in the EP

\begin{tabular}{|c|c|c|c|}
\hline Member state & $\begin{array}{l}\text { EU-27: New } \\
\text { allocation of seats }\end{array}$ & $\begin{array}{l}\text { EU-15: Current } \\
\text { allocation of seats }\end{array}$ & $\begin{array}{l}\text { Difference between } \\
\text { EU-15 and EU-27 }\end{array}$ \\
\hline Germany & 99 & 99 & 0 \\
\hline UK & 72 & 87 & -15 \\
\hline France & 72 & 87 & -15 \\
\hline Italy & 72 & 87 & -15 \\
\hline Spain & 50 & 64 & -14 \\
\hline Poland & 50 & - & - \\
\hline Rumania & 33 & - & - \\
\hline Netherlands & 25 & 31 & -6 \\
\hline Greece & 22 & 25 & -3 \\
\hline Czech Rep. & 20 & - & - \\
\hline Belgium & 22 & 25 & -3 \\
\hline Hungary & 20 & - & - \\
\hline Portugal & 22 & 25 & -3 \\
\hline Sweden & 18 & 22 & -4 \\
\hline Bulgaria & 17 & - & - \\
\hline Austria & 17 & 21 & -4 \\
\hline Slovakia & 13 & - & - \\
\hline Denmark & 13 & 16 & -3 \\
\hline Finland & 13 & 16 & -3 \\
\hline Ireland & 12 & 15 & -3 \\
\hline Lithuania & 12 & - & - \\
\hline Latvia & 8 & - & - \\
\hline Slovenia & 7 & - & - \\
\hline Estonia & 6 & - & - \\
\hline Cyprus & 6 & - & - \\
\hline Luxemburg & 6 & 6 & 0 \\
\hline Malta & 5 & - & - \\
\hline Total EU-27 & 732 & 626 & 91 \\
\hline
\end{tabular}


732, well beyond the limit of 700 set at Amsterdam, courtesy of the new Art. 189(2). Article 2 of the Protocol on the Enlargement attached to the NIT states that the total number of MEPs for the period 2004-9 will be equal to the number of seats specified in Art. 190(2) TEC plus a number of MEPs from the member states that will sign their Accession Agreements to the Union. If the total number of MEPs is less than 732 it will be corrected in such a way so that it will be as close to that number as possible. The correction will be made by the Council and the total number of MEPs may be temporarily higher than 732 if new members accede after the corrective decision of the Council.

The new Art. 300(6) offers the EP the same right as the other major EU institutions, namely the right to appeal in front of the ECJ for questioning the compatibility of international agreements with the EU legal order. If these agreements are found by the ECJ to be incompatible with the Community's legal order, then these can enter into force with the procedure specified in Art. 48 TEC, that is, after ratification by national parliaments. Other changes related to the EP include Art. 191 on European political parties, which has been changed so that 'a legal basis for the financing of the political parties could be created' according to the reasoning offered by the Commission. ${ }^{27}$ In the new Art. 191, a paragraph was inserted under which the Council and the EP (co-decision) are authorised to issue regulations on the financing of political parties after observing certain conditions. The EP, by virtue of the reformed Art. 190(5), is given the right to draw the statute (regulations and general conditions governing the performance of the duties of its members) of the MEPs requiring also QMV in the Council and an opinion by the Commission, although the taxation issues of the MEPs will require unanimity in the Council.

\section{The ECJ}

The ECJ, in spite of the pro-integration activism that characterised its rulings over time, was very careful to avoid addressing the political issues in the agenda of the IGC 2000, preferring instead to focus on issues directly involving its organisational set-up, improvements in its workings, the creation of special bodies - Judicial Panels, to take up cases involving the employees of EU institutions - and the allocation of the workload between itself and the Court of First Instance. ${ }^{28} \mathrm{All}$ in all, the ECJ tabled five proposals in the IGC, three of which were of major importance. First, the ECJ and the Court of First Instance asked to acquire the right to modify their Rules of Procedure as is the case with the European Court of Human Rights and the International Court of Justice in The Hague, in the place of the present arrangement under which this is the task of the Council acting unanimously. The Nice Summit granted the ECJ the right to draw its Rules of Procedure to be decided by the Council acting on QMV. As a result, Arts 223 and 224 were modified accordingly. Second, the ECJ asked for the introduction of a screening system on the choice of cases to be addressed to it, involving annulment of decisions by the Court of First Instance. The Treaty was thus modified to give the latter the right to hear at second degree decisions 
by the Judicial Panels (Art. 225(2)). It also granted the ECJ the right to hear at second degree decisions by the Court of First Instance. After the entry into force of the NIT, the Court of First Instance acquires the right to hear cases under the following Articles:

- Art. 230, legality of Acts adopted jointly by the EP and the Council, of Acts of the Council, of the Commission and of the European Central Bank (ECB), other than recommendations and opinions, and of Acts of the EP intended to produce legal effects vis-à-vis third parties.

- Art. 234, preliminary ruling giving under conditions the right to the Court of First Instance to refer to the ECJ, and to the ECJ the right to review, under conditions, decisions by the Court of First Instance.

- Art. 230, direct action.

- Art. 238, arbitration.

- Art. 236, employment differences involving employees of EU institutions.

- Art. 225(2), decisions of the Judicial Panels. Successive declarations by the governments of the member states attached to the Treaty clarify the details in the implementation of this Article.

- Art. 229a, the ECJ acquired the right to review cases related to industrial property.

Overall, this is a major review of the EU judicial system, which is expected to have significant consequences in the future direction of the integration process. Students of European integration should be aware of such developments, principally because they are expected to contribute further to the political activism of the ECJ.

\section{The ESC and the CoR}

In its opinion on the IGC $2000,{ }^{29}$ the ESC presented a shopping list designed to improve its status in the interinstitutional balance of power within the Union. In fact, it tabled four main demands. First, it should be stated clearly in the new Treaty that the ESC is an important forum of social dialogue. Second, the ESC should acquire the role of a moderator in cases where the Treaty requires its opinion on complex issues. Third, the obligatory consultation of the ESC by the Commission when the latter prepares its legislative proposals. Fourth, the term of the ESC should be five years, to coincide with those of the Commission and the EP. All of the above demands were rejected by the Nice Summit. For its part, the CoR in effect adopted the positions of the EP as stated above and demanded that the regions be acknowledged as having equal status with the national and Community levels, ${ }^{30}$ by reforming Art. 5. Such a demand was also rejected by the Summit. There was, however, a reallocation of seats in both institutions in order to take into account the prospects for further enlargement, as shown in Table 4.16. All of the current member states retain the same 
number of seats after Nice and the total membership in both institutions increases from the current 222 to 344 (not more than 350 in the wording of the NIT) after enlargement (EU-27).

Table 4.16 New allocation of seats for the Economic and Social Committee (ESC) and the Committee of the Regions (CoR)

\begin{tabular}{lcc}
\hline Member state & New allocation after Nice & Current allocation \\
\hline Germany & 24 & 24 \\
UK & 24 & 24 \\
France & 24 & 24 \\
Italy & 24 & 24 \\
Spain & 21 & 21 \\
Poland & 21 & - \\
Rumania & 15 & - \\
Netherlands & 12 & 12 \\
Greece & 12 & 12 \\
Czech Rep. & 12 & - \\
Belgium & 12 & 12 \\
Hungary & 12 & - \\
Portugal & 12 & 12 \\
Sweden & 12 & 12 \\
Bulgaria & 12 & - \\
Austria & 12 & 12 \\
Slovakia & 9 & - \\
Denmark & 9 & 9 \\
Finland & 9 & 9 \\
Ireland & 9 & 9 \\
Lithuania & 9 & - \\
Latvia & 7 & - \\
Slovenia & 7 & - \\
Estonia & 7 & - \\
Cyprus & 6 & - \\
Luxembourg & 6 & 6 \\
Malta & 5 & - \\
Total EU-27 & 344 & 222 \\
\hline
\end{tabular}

\section{Unanimity, QMV and co-decision}

Table 4.17 sums up the modest results of the IGC 2000 and the Nice Summit. All in all, forty-nine provisions came up for negotiations including some representing a clear procedural anomaly such as that of Art. 42 (measures of social protection in the context of the free movement of persons) or Arts 62, 63 and 67, which require simultaneously unanimity in the Council and co-decision with the EP. The Commission proposed that unanimity should be preserved in 
Table 4.17 From unanimity to QMV

\begin{tabular}{|c|c|c|}
\hline Article & Subject & Notes \\
\hline 7.1 & $\begin{array}{l}\text { Establishment of a breach of fundamental } \\
\text { rights by a member state }\end{array}$ & $\begin{array}{l}4 / 5 \text { Council special super- } \\
\text { qualified majority }\end{array}$ \\
\hline 23.2 & Nomination of special representatives of CFSP & \\
\hline 24 & Binding international agreements CFSP/JHA & \\
\hline 13.2 & Measures to promote non-discrimination & QMV and co-decision \\
\hline 18.2 & Free movement of persons & QMV and co-decision \\
\hline 65 & $\begin{array}{l}\text { Judicial cooperation in civil matters excluding } \\
\text { family law }\end{array}$ & QMV and co-decision \\
\hline 67 & Common rules on asylum policy & Unanimity and co-decision \\
\hline 100 & Emergency aid for natural disasters & EP informed \\
\hline 111.4 & $\begin{array}{l}\text { International representation in economic and } \\
\text { monetary policy }\end{array}$ & \\
\hline 123.4 & Introduction of the Euro to new member states & \\
\hline 133 & $\begin{array}{l}\text { Trade in services and commercial aspects of } \\
\text { intellectual property (with exceptions) }\end{array}$ & \\
\hline 137 & $\begin{array}{l}\text { QMV and co-decision may be used for protection } \\
\text { of sacked workers, co-determination and collective } \\
\text { protection of workers and employers and conditions } \\
\text { of employment of legitimate third-country nationals }\end{array}$ & \\
\hline 157 & Measures to support action in industrial policy & QMV and co-decision \\
\hline 159 & $\begin{array}{l}\text { Action to support economic and social cohesion } \\
\text { outside structural funds }\end{array}$ & QMV and co-decision \\
\hline 161 & Reform of structural and cohesion funds & $\begin{array}{l}\text { QMV and assent of EP as } \\
\text { from } 2007\end{array}$ \\
\hline $181-$ & $\begin{array}{l}\text { Economic, financial and technical co-operation } \\
\text { with third countries }\end{array}$ & \\
\hline 190.5 & MEPs statute except taxation & \\
\hline 191 & Statute of political parties & QMV and co-decision \\
\hline 207.2 & $\begin{array}{l}\text { Appointment of Secretary General and Deputy } \\
\text { Secretary General of the Council }\end{array}$ & \\
\hline 210 & Salaries and pensions of Court of First Instance & \\
\hline 214 & $\begin{array}{l}\text { Nomination appointment and replacement of } \\
\text { members of the Commission }\end{array}$ & \\
\hline 223 & Rules of Procedure of ECJ & \\
\hline 224 & Rules of Procedure of the Court of First Instance & \\
\hline 247 & Appointment of the Court of Auditors & \\
\hline 248 & Adoption of Rules of Procedure of the Court of Auditors & \\
\hline 259.1 & Appointment of ESC & \\
\hline 263 & Appointment of CoR & \\
\hline 279 & Financial regulation for EU budget & As from 2007 \\
\hline
\end{tabular}


five groups of decisions and that QMV should become the dominant modus decidendi in the EU; ${ }^{31}$ these were:

- In the case of Arts 22, 190(4) and 269, according to which any decisions taken have to be ratified by national Parliaments.

- In thirteen cases related to institutional issues affecting the political equilibrium between the member states (Arts 67(2), 100(1), 100(2), 104(14), 107(5),123(5), 202, 221, 222, 225(2), 245, 290, 308).

- In three cases related to taxation and social policy not related to the internal market (Arts 93, 95, 137(3)).

- In three cases related to deviations from the internal market rules (Arts 57(2), 72, 88(2)).

- In four cases of unity of law between international agreements and internal legislation (Arts $111(1), 187,300,310)$ ).

However, reactions by a number of member states but principally from the UK, Sweden and Denmark and to a lesser extent from France, Ireland, Spain and Luxembourg, resulted in the decision of the Nice Summit which is shown in Table 4.17, according to which twenty-seven provisions move to QMV,

\section{Enhanced co-operation}

The debate about 'flexibility' or 'enhanced co-operation' is old enough to be traced back to Dahrendorf, who proposed an à la carte arrangement of the Community as early as 1979 and continued with Giolliti in 1982,32 who suggested that differentiation should become a principle of the Community's future evolution. Stubb undertook the useful task of explaining the jargon used on this issue in several European languages. ${ }^{33}$ The term 'variable geometry' refers to a situation in which several member states co-operate in order to satisfy specific objectives in a more or less exclusive fashion, in the knowledge that the rest of the members cannot participate lacking the necessary know-how (and knowwhy) prerequisites. Examples of this kind of co-operation are abundant during recent years. The Eureka project, the JET project, the Airbus or the ESA, ${ }^{34}$ all involve interstate co-operation outside the formal confines of the Treaties and are all more or less permanent and exclusive forms of international cooperation. In an à la carte co-operation scheme, the member states are allowed to choose the kind of co-operation to be associated with and accept their participation in the attainment of a limited number of common objectives. The idea of 'multispeed co-operation' involves several member states in a less exclusive fashion than before, in which other members will be allowed to join in whenever they find it advisable. ${ }^{35}$

The AMT (see Chapter 3) introduced the 'flexibility' provisions in Arts 11 TEC, 43 and 44 AMT. The relevant provisions have not been used up to now, principally because it was felt that such provisions were introducing scores of 
strict requirements that were not facilitating the development of such forms of co-operation. The French Presidency circulated a questionnaire to the representatives of the member states in the IGC that attempted to pinpoint the reasons for the non-use of the flexibility clauses. ${ }^{36}$ Returns from the questionnaire almost unanimously blamed the plethora of requirements in the AMT. The flexibility clauses became part of the IGC agenda during the Portuguese Presidency. The latter's Report to the Santa Maria de Feira Summit revealed that during the IGC two alternative scenarios were discussed for changing the flexibility clauses: the Report calls the first scenario 'the enabling clauses scenario', drawing from the situation in the first and third pillars; the second scenario is referred to as the 'predetermined model', rooted in the Schengen and EMU provisions and experience and attempted to built on the AMT provisions. ${ }^{37}$ It was the latter scenario that effectively prevailed. The reasons advanced in the Report relate to the challenge of further enlargements and in particular the avoidance of the impression that the changes in the flexibility clauses were taking place with the prospective members in mind. Possible areas of enhanced co-operation were also mentioned in the Report such as the CFSP and defence, police and judicial co-operation, the environment, research and development (R\&D), and industrial co-operation. The EP through the Delgado Report also supported the envisaged changes in the AMT provisions. ${ }^{38}$

\section{Changes with the Treaty of Nice}

There were two important changes in the clauses on enhanced co-operation: the first involved a change in the minimum number of member states to embark on such projects, from the majority of the member states in the AMT to eight in the new Treaty. Second, the 'emergency brake' procedure was abandoned, according to which the whole issue could be referred to the European Council to make a unanimous decision (see Chapter 3). This was replaced by a provision whereby a proposal for enhanced co-operation may be deferred to the European Council by the Council of Ministers acting on QMV, which will discuss the proposal, but no vote will be taken. The proposal will then go back to the Council of Ministers to decide by QMV.

According to Art. B, any enhanced co-operation will be regarded as a solution of the 'last resort' in the sense that any decision to that effect will be taken only if it becomes plain that the required majorities in the Council will not be forthcoming and the Union cannot move in toto towards new areas of cooperation. Art. C gives the opportunity to any member state to join in an enhanced co-operation scheme at any time, provided that they 'respect the basic decision and the decisions taken herewith'. Moreover, Art. D asserts the institutional procedures to be adopted in the context of enhanced co-operation. All Council members are allowed to take part in the deliberations, but only the participating members have a right to vote. Decisions will be taken by QMV defined for the purposes of the enhanced co-operation as a proportion of the weighted votes and as a proportion of the number of the participating states. Unanimity consists exclusively of the latter, whereas the decisions adopted within an 
enhanced co-operation will not form part of the acquis communautaire and will be binding only on the participating states. Consistency between the policies of the Union and those involved in an enhanced co-operation is left to the co-operation between the Council and the Commission.

In the first pillar, the interested member states must submit an application for enhanced co-operation to the Commission. The latter may submit a proposal to that effect to the Council or notify the applicant member states for the reasons of not doing so. In the first pillar, the whole process rests decisively with the Commission. If it chooses not to submit a relevant proposal to the Council, then the whole process stops right there since there is no alternative open for the applicant member states. The Council, acting by QMV on a proposal from the Commission and after consulting the EP (or with its assent if the proposal concerned relates to an issue area covered by co-decision), will give authorisation to set up such flexible integration schemes. Any operating expenditure will be borne by the participating members, whereas the expenditure associated with EU institutions will be borne by the general budget.

There is also a provision in Art. E giving the opportunity to a unanimous Council to decide that all costs associated with enhanced co-operation is covered by the general budget of the Union. According to clause $\mathrm{H}$, any member state wishing to participate in an enhanced co-operation in the first pillar must notify the Council and the Commission of its intentions. The latter will give its opinion on the subject to the Council within three months and will reach a decision on the member state's request within four months of its submission. Clauses I-M refer to the conditions for establishing a framework of enhanced co-operation in the second pillar. This must respect the principles, general guidelines and consistency of the CFSP and the decisions taken in this context, the powers of the Community, and must observe that there is consistency between the policies of the Union and its external activities.

According to clause $\mathrm{J}$, the foundation of enhanced co-operation in the second pillar relates only to the implementation of a common action or a joint decision and is forbidden expressis verbis in matters having military or defence implications. The new Treaty, in its clause L, assigns to the High Representative of the CFSP - the Secretary General of the Council - the task, if not duty, of fully informing all members of the Council on the implementation of enhanced co-operation in second-pillar issues. Clause $\mathrm{M}$ specifies the procedure allowing other member states to join in an enhanced co-operation scheme in the CFSP framework. These must notify the Commission and the Council of their intentions. Within three months the Commission shall give its opinion to the Council, which will decide by QMV within four months, unless it decides to hold the member states' request in abeyance, though specifying a date for the re-examination of the issue.

Clause $\mathrm{O}$ specifies the procedure for enhanced co-operation in the third pillar. Again, the interested member states must address a request to the Commission, which in turn must decide whether to submit a proposal to the Council. If the Commission decides not to submit a proposal, it must notify the 
member states concerned of the reasons of not doing so. Contrary to the arrangements in the first pillar, in the third pillar, interested members are given the option to initiate a discussion in the Council which, after consulting the EP and acting by QMV, may concede authorisation. Other member states wishing to join an enhanced co-operation scheme in the third pillar (Clause P) will have to go through a procedure similar to that described in the case of the CFSP. Table 4.18 summarises the situation in each pillar.

Table 4.18 Enhanced co-operation

\begin{tabular}{llll}
\hline Pillar & Initiative & Proposal & Decision \\
\hline EC & Member state $(\min .8)$ & Commission & Commission \\
CFSP & Member state $(\min .8)$ & Commission & Council/ QMV \\
CJHA & Member state $(\min .8)$ & $\begin{array}{l}\text { Commission or } \\
\text { member states }\end{array}$ & Council/QMV \\
& & & \\
\hline
\end{tabular}

\section{Concluding remarks}

The negotiations during the IGC and the Nice Summit were successfully concluded, in the sense that a compromise was eventually struck, leading to a new institutional equilibrium. The bigger member states, above all Germany and to a lesser extent Spain, seem to be on the winning side if we reflect on the new equilibrium in each of the EU institutions. But the decision-making system in the Council has become less citizen-friendly, if not more complex and conspicuously less efficient. It comes as no surprise, therefore, that a Final Declaration attached to the NIT calls for yet another reform process leading to an IGC in 2004, which may in turn lead to a new Treaty (see Chapter 7). The rationale for further reform attempts to face the 'real' issues of the EU's evolving agenda: democratic participation, openness and transparency in decision-making, civic rights and duties, the wider issue of the constitutional identity of the Union and, in short, the perennial issue of legitimising its political constitution. Before moving on to these themes, Chapters 5 and 6 attempt to assess the international post-Cold War environment and the new European security architecture.

\section{Notes}

1 See Treaty of Amsterdam, Protocol No 7, p. 111.

2 Ibid.

3 Presidency Conclusions of the European Council in Cologne, SN 150/99, para. 52, p. 20

4 Ibid., p. 53.

5 Presidency Conclusions of the European Council in Helsinki, SN 300/99, 10-11/12/1999, paras 15-18. 
6 See CONFER 4750/00, 14 June 2000, p. 5 ff.

7 Added at the Santa Maria de Feira Summit.

8 See 'Adapting the Institutions to make Success of Enlargement' COM (99) 592 Final, November 101999.

9 See European Parliament, A5-0086/2000, 13 April 2000, point 31.1.

10 European University Institute, 'A Basic Treaty for the European Union', Robert Schumann Center for Advanced Studies, 15 May 2000.

11 See COM (2000) 34 Final, paras 11-26, 26 January 2000.

12 Ibid., para. 12.

13 Indeed, the new Commission President Romano Prodi, who took over after the resignation of the Santer Commission in 1999, set up a plan ending in 2002. This plan was published in COM (2000) 200 Final, Vols 1 and 2 (Action Plan), 'Reforming the Commissin: A White Paper'. The internal reorganisation of the Commission was based on five principles: independence from sectional, national or other influences; responsibility; control, promoting a culture of co-operation between the stuff of the Commission; efficiency and simplification of administrative processes; and transparency, internally and towards the citizens of the Union.

14 See Revised Summary CONFER 4815/00, 30 November 2000, pp. 64-5.

15 Ibid.

16 SN 533/00, p. 76

17 Report of the Portuguese Presidency, p.18 and especially the attached Annexes.

18 SN 533/00, Treaty of Nice, Annex 1, pp. $74 \mathrm{ff}$.

19 SN 533/00, Treaty of Nice, Protocol on the Enlargeent of the European Union, 12 December 2000, pp. 74 ff.

20 See W. Wessels, 'Nice Results: The Millenium IGC in the EU's Evolution', Journal of Common Market Studies, 39:2, 2001, pp. 197-219.

21 See 'Report on the European Parliament's Proposals for the Intergovernmental Conference', A5-0086/2000 Final, 27/3/2000 Part 1.

22 Ibid., p. 6

23 Ibid., p. 7.

24 Ibid., pp. 7-8

25 Ibid., p. 8.

26 Ibid., p. 9.

27 See COM (2000) 444 Final, 12/7/2000, Communication from the Commission. Additional Commission Contribution to the Intergovernmental Conference. Regulations Governing Political Parties.

28 See 'Contribution of the Court of Justice and of the Court of First Instance to the IGC'. The document can be found at the EU/ECJ Internet site 'europa'.

29 Opinion of the ESC, 'IGC 2000 and the role of the ESC', Brussels, 1 March 2000.

30 See 'Opinion of the Committee of the Regions on the IGC', 17 February 2000, Committee on Institutional Affairs/005, 32A.

31 See COM (2000) 34 Final, 26 January 2000.

32 Reported by W. Wallace, 1982, p. 433.

33 See C.-G. A. Stubb, 'A Categorization of Differentiated Integration', Journal of Common Market Studies, 34:2, 1996, pp. 283-95.

34 Stubb, 'A Categorization', p. 286

35 Ibid.

36 CONFER 4758/11, July 2000. Note of the French Presidency.

37 CONFER 4750/00, p. 51

38 See EP 2000/2162 (INI), Committee on Constitutional Affairs, 12 October 2000. 